\title{
„Oswajanie” Norwegii - wzory osiedleńcze polskich migrantów w Norwegii
}

Celem artykułu jest analiza wzorów osiedleńczych polskich migrantów i ich rodzin w Norwegii oraz przybliżenie mechanizmów, przez które zachodzi ich adaptacja do życia w Norwegii. Artykuł oparty jest na badaniach jakościowych (wywiady z 24 rozmówcami, zima-lato 2014) i ilościowych (ankieta internetowa, maj i czerwiec 2015 r., 648 osób) przeprowadzonych w ramach projektu TRANSFAM, jak również na oficjalnych statystykach i rezultatach wcześniejszych badań. Autorka wykorzystała ponadto rezultaty obserwacji poczynionych podczas pobytu w Oslo, gdzie w sierpniu 2016 r. przebywała jako visiting researcher na uczelni Oslo and Akershus University College of Applied Sciences. Zebrany materiał pozwala stwierdzić, że bez względu na początkowe plany Polacy wydłużają swój pobyt w tym kraju. Wraz z rozwojem sieci migracyjnych oraz wzrostem liczby dzieci rodzących się w Norwegii i sprowadzanych przez rodziców do tego kraju, czasowa migracja Polaków przybiera formę długotrwałego pobytu. Dominujący po 2004 r. wzór czasowych migracji przeważnie mężczyzn zostaje uzupełniany przez długookresowe migracje rodzinne.

Słowa kluczowe: polscy imigranci, Norwegia, migracje rodzinne

\section{“Appropriating” Norway - Polish Migrants' Settlement Patterns in Norway}

The article aims to analyze Polish migrants and their family migration patterns to Norway, as well as how they adjust to the new country. It is based on qualitative (24 interviews, wintersummer 2014) and quantitative (web-survey, May-June 2015, 648 respondents) research conducted in the framework of the TRANSFAM project. Official statistics and earlier study results are also applied. The author gained additional knowledge from observations made during her visit as a visiting researcher at Oslo and Akershus University College of Applied Sciences. On the basis of the analysed material, it can be concluded that regardless of their initial plans, Poles

\footnotetext{
${ }^{1}$ Kontakt: k.gmaj@lazarski.edu.pl
} 
prolong their stay in Norway. Together with the development of a migrants network and a growing number of children born there or brought by their parents, Polish migrants' stay in Norway turns into a long-term one. A dominant pattern of primary male migration at the beginning of the $21^{\text {st }}$ century has been accompanied by the stable family migration pattern.

Keywords: Polish migrants, Norway, family migration

Artykuł oparty jest na rezultatach badań jakościowych i ilościowych przeprowadzonych w ramach projektu TRANSFAM ${ }^{2}$ oraz na oficjalnych statystykach. Autorka wykorzystała ponadto rezultaty obserwacji z pobytu w Oslo, gdzie w sierpniu 2016 r. przebywała jako visiting researcher na Wydziale Pracy Socjalnej, Opieki nad Dziećmi i Polityki Społecznej Oslo and Akershus University College of Applied Sciences. Celem artykułu jest analiza wzorów osiedleńczych polskich migrantów i ich rodzin w Norwegii (patrz także Gmaj 2016).

$\mathrm{W}$ analizie jakościowej wykorzystano wywiady z 24 rozmówcami. Dziesięć $\mathrm{z}$ nich to wywiady biograficzne, $\mathrm{w}$ tym cztery z obojgiem małżonków. Odbyły się zimą i wiosną 2014 r. w Oslo i miejscowościach odległych od niego nie więcej niż dwie i pół godziny drogi samochodem ${ }^{3}$. Pozostałe osiem to wywiady ustrukturyzowane przeprowadzone latem 2014 r. z dziesięcioma imigrantami z Polski mieszkającymi w miejscowościach należących do okręgów Vest Agder i Aust Agder

Spośród wszystkich rozmówców tylko jeden był w związku z Norwegiem. Pozostałych relacje rodzinne wiązały z Polakami. Rozmówcy mieli co najmniej sześcioletnie doświadczenie pobytu w Norwegii. Najdłuższy pobyt to prawie ćwierć wieku, ale tylko sześcioro badanych po raz pierwszy przybyło do Norwegii przed majem $2004 \mathrm{r}$. Na przestrzeni czasu zmieniała się forma ich pobytu. Zmieniała się długość okresów spędzonych w Polsce i Norwegii, rodzaj podejmowanych prac (praca rejestrowana i nierejestrowana, czasowa lub na stałe, $\mathrm{w}$ pełnym wymiarze godzin czy w niepełnym wymiarze czasu pracy itp.), przebywanie za granicą bez rodziny lub z rodziną (małżonek, dzieci, rodzice oraz rodzeństwo). Rozmówcy zróżnicowani byli pod względem poziomu i typu wykształcenia (osiągniętego w Polsce i Norwegii), wcześniejszych doświadczeń migracyjnych (spoza Norwegii) i sytuacji zawodowej w obu krajach oraz poziomu religijności. Kwestia wzorów osiedleńczych była jedną z wielu poruszanych w badaniu kwestii.

${ }^{2}$ Projekt finansowany ze środków funduszy norweskich, w ramach programu Polsko-Norweska Współpraca Badawcza realizowanego przez Narodowe Centrum Badań i Rozwoju w ramach Norweskiego Mechanizmu Finansowego na lata 2009-2014 w ramach kontraktu nr Pol-Nor/197905/4/2013. Na temat projektu więcej przeczytać można na jego stronie: http://www.transfam.socjologia.uj.edu.pl.

3 Autorce udostępniono dziesięć spośród 30 wywiadów, zebranych w ramach zadania 2. Rodziny migranckie $w$ Norwegii / struktury relacji władzy i negocjacji wartości i norm w rodzinach transnarodowych (lider: dr Magdalena Ślusarczyk).

${ }^{4}$ Materiał zebrano w ramach zadania 3. Kapitał społeczny polskich imigrantów w Norwegii (lider: dr Eugene Guribye). 
W analizie ilościowej autorka opisuje wyniki ankiety internetowej ${ }^{5}$, w której w maju i czerwcu 2015 r. wzięło udział 648 osób, z których 633 żyły w związkach (formalnych i nieformalnych), a 15 określiło się jako samodzielnie wychowujące dzieci. Wśród respondentów przeważają kobiety (60 proc. próby, ale ich udział procentowy w populacji migrantów jest prawie dwukrotnie niższy); 47 proc. respondentów miało wykształcenie wyższe, 40 proc. średnie. W zdecydowanej większości przybyli do Norwegii w 2004 r. lub później ( 585 z 607 udzielonych odpowiedzi). Na podkreślenie zasługuje fakt, że dla jednej trzeciej respondentów i 27 proc. ich partnerów Norwegia nie jest pierwszym krajem, w którym mieszkali poza Polską dłużej niż trzy miesiące. Pod tym względem rysuje się podobieństwo z częścią rozmówców biorących udział w wywiadach biograficznych i ustrukturyzowanych, którzy przed przybyciem do Norwegii także mieli wcześniejsze doświadczenia migracyjne.

Zebrany materiał wskazuje, że bez względu na początkowe plany Polacy wydłużają swój pobyt w tym kraju. Dominujący po 2004 r. wzór czasowych migracji przeważnie mężczyzn zostaje uzupełniany przez długookresowe migracje rodzinne. Mechanizmy napływu i strategie migracyjne do nienależącej do Unii Europejskiej Norwegii są bardzo podobne do tych obserwowanych w migracjach do krajów do niej należących, w tym Wielkiej Brytanii. Artykuł przedstawia ważny, w kontekście brexitu, materiał zarówno dla polskich czy brytyjskich badaczy, jak i dla polityków.

\section{Norwegia jako kraj imigracyjny}

Do lat 70. XX w. Norwegia była krajem emigracyjnym. Jednak w związku z rozwojem gospodarki po II wojnie światowej stopniowo zaczęła otwierać się na migracje pracownicze, zgadzając się na swobodny przepływ pracowników pomiędzy krajami skandynawskimi. W połowie lat 70. pojawili się nisko wykwalifikowani pracownicy z Pakistanu i Turcji. Zatrudnienie znaleźli w przemyśle i usługach. Pomimo wprowadzenia bardziej restrykcyjnej polityki migracyjnej wobec osób z krajów słabo rozwiniętych, Norwegia nie zatrzymała ich napływu, a jedynie zmieniła charakter migracji z pracowniczych na łączenie rodzin. Lata 80. i 90. to okres napływu uchodźców z różnych stron świata. W latach 90. wprowadzono program kwot dla pracowników sezonowych z Europy Środkowo-Wschodniej, głównie Polski. Do 2004 r. regulacje dotyczące swobodnego przepływu pracowników w ramach Europejskiego Obszaru Gospodarczego nie miały właściwie wpływu na imigrację do Norwegii. Dla pracowników pochodzących z państw nowo przyjętych do UE (EU-8) Norwegia wprowadziła okres przejściowy w dostępie do swojego rynku

${ }^{5}$ Część zadania 4. Rodzicielstwo w perspektywie cyklu życia (lider: Lihong Huang, starszy badacz). Więcej informacji na temat samej ankiety oraz jej rezultatów znaleźć można w: Huang i in. (2015, 2016). 
pracy. Trwał on do 2009 r. W jego trakcie obowiązywał wymóg uzyskania rocznego kontraktu na pełny etat na warunkach porównywalnych do tych oferowanych norweskim pracownikom (Baba, Dahl-Jørgensen 2010).

Na początku 2016 r. imigranci stanowili 13,4 proc. populacji Norwegii (698 600), a osoby urodzone w Norwegii mające oboje rodziców imigrantów (matkę i ojca oraz czworo dziadków urodzonych poza Norwegią) - 2,9 proc. (149 700). Polacy, będąc okołostutysięczną grupą, są najliczniejsi (ok. 14 proc. wszystkich imigrantów). Litwini, Szwedzi liczący po około 40 tys. i Somalijczycy - około 30 tys. to kolejne pod względem liczebności grupy. Wśród osób urodzonych w Norwegii i mających rodziców przybyłych spoza Norwegii najwięcej jest tych, których rodzice pochodzą z Pakistanu i Somalii, a następnie tych, których rodzice to Polacy (Statistics Norway 2016).

\section{Wzory osiedleńcze migrantów międzynarodowych}

Najszerzej rzecz ujmując, osiedlanie się (settlement) to proces dostosowywania się do życia w nowym społeczeństwie i budowanie poczucia bycia u siebie. Problematyczne jest wyznaczenie jednoznacznego momentu, w którym uznać można ten proces za zakończony, czego odzwierciedleniem jest literatura na temat drugiego pokolenia migrantów (second generation migrant) (np. Portes, Zhou 1993; Perlmann, Waldinger 1997; Modood i in. 1997; Waters 1999; Apitzsch 2005; Kasinitz i in. 2008). Analizy procesów osiedleńczych odzwierciedlają, po pierwsze, zmiany w relacjach między społeczeństwem przyjmującym i migrantami, a po drugie zmiany w charakterze i wzorach samych migracji.

Nie sposób przedstawić w całości bogatej debaty naukowej i publicznej dotyczącej relacji między imigrantami a społeczeństwem przyjmującym, ale można wskazać dominujące w niej podejścia: asymilacyjne, integracyjne i wielokulturowe (Castles, Miller 2011; Philips 2009; Kymlicka 2009; Levey, Modood 2009; Alba, Nee 1997).

W podejściu asymilacyjnym włączenie imigrantów odbywa się w wyniku ich jednostronnej adaptacji i wiąże się z odrzuceniem kulturowej tożsamości kraju pochodzenia. Zakończony sukcesem proces osiedlenia to osiągnięcie przez migranta „niewidzialności” . Poza początkowym okresem po przyjeździe zarówno poszczególne osoby, jak i grupy imigranckie powinny wtopić się w społeczeństwo - nie powinny różnić się pod względem swoich potrzeb od reszty.

Podejście integracyjne wskazuje na stopniowość i potrzebę wzajemności w procesie dostosowania się ze strony imigrantów i społeczeństwa przyjmującego. Chociaż utrzymywanie różnic grupowych w dłuższym okresie jest akceptowane, to końcowy cel pozostaje tożsamy z podejściem asymilacyjnym - wchłonięcie imigrantów przez społeczeństwo większościowe. 
Podejście wielokulturowe akceptuje współistnienie wielu kultur w jednym państwie oraz oczekuje, że imigranci (i ich potomkowie) powinni móc uczestniczyć na równych prawach we wszystkich dziedzinach życia społecznego. Ze strony migrantów wymaga dostosowania się do pewnych kluczowych wartości. W związku ze zwiększającym się zróżnicowaniem społeczeństw w europejskiej debacie dotyczącej imigrantów coraz częściej podkreśla się kwestię ich partycypacji, w tym szczególnie partycypacji politycznej. Aktywność imigrantów w obszarze polityki i partii politycznych ma wspomóc sprawczość imigrantów, co w dłuższej perspektywie służyć ma utrzymaniu spójności społecznej. Z jednej strony aktywność polityczna prowadzić ma do integrowania imigrantów z państwem, z drugiej zapewnić im wpływ na rozwój wszystkich obszarów społecznych (Iglicka, Gmaj 2015).

W badaniach na temat integracji imigrantów pod uwagę brane są różne aspekty, w tym integracja przestrzenna. Najczęściej odnosi się ją do dostępu imigrantów do mieszkań, wyboru miejsca zamieszkania, a także wpływu tychże na ich sytuację społeczno-ekonomiczną (Buhr 2014). Wiele badań wskazuje na wysoki stopień koncentracji geograficznej imigrantów, co postrzegane jest jako nieunikniony produkt imigracji, zwłaszcza w przypadku nowych imigrantów uzależnionych od pomocy krewnych czy rodaków. Koncentracji imigrantów towarzyszą obawy wyrażane przez część uczonych, polityków i decydentów. Dotyczą one skupiania się migrantów w obszarach zdegradowanych, braku równych szans życiowych wynikających z miejsca zamieszkania oraz tworzenia „równoległych społeczeństw”, oddzielonych od głównego nurtu społeczeństwa. W obecnym dyskursie politycznym zjawisko koncentracji przestrzennej imigrantów zostało upolitycznione i pokazywane jest jako zagrożenie dla spójności społecznej, chociaż wyniki badań empirycznych nie są w tym względzie jednoznaczne i nie pozwalają na proste łączenie integracji i segregacji przestrzennej (Bolt, Ozuekren, Phillips 2012).

$\mathrm{W}$ analizach wzorów migracji postakcesyjnych w literaturze pojawia się pojęcie "płynnej migracji” (liquid migration) (Engbersen i in. 2010; Engbersen, Snel 2013; Glorius i in. 2013), której jedną z głównych cech jest brak przewidywalności. Osiedlanie się zyskuje nowy wymiar, bo charakter pobytu jest tymczasowy, a pozostawienie „otwartej opcji” staje się częścią migranckiego habitusu, związaną ze swobodnym przepływem pracowników w państwach członkowskich UE i EOG. W analizach tych wskazuje się na współwystępowanie "starych” i „nowych” wzorów migracji i na to, że ich wyjaśnianie wymaga stosowania różnych podejść (Glorius i in. 2013).

Z perspektywy migrantów przydatne jest uwzględnienie kwestii percepcji przestrzeni, czyli złożonego procesu intelektualnego i emocjonalnego, w którym jednostki są aktywnymi odbiorcami i użytkownikami środowiska (Wallis 1990). Analizując wzory osiedleńcze, warto uwzględnić, że sposób, w jaki ludzie postrzegają rzeczywistość przestrzenną, kształtowany jest nie tylko przez jej materialną właściwość, ale także przez ich indywidualne cechy. Co więcej, istotną rolę 
odgrywają wcześniejsze doświadczenia związane z takimi samymi lub uznanymi za analogiczne sytuacjami oraz oczekiwaniami dotyczącymi przyszłych celów, które mają zostać zrealizowane w danym miejscu (Kaltenberg-Kwiatkowska 2007). Zasadne wydaje się przypomnienie koncepcji miejsca (place), czyli uczłowieczonej przestrzeni (humanized space) (Tuan 1987). Człowiek nie może istnieć i normalnie funkcjonować w zupełnie obcej, nieznanej i niezinternalizowanej przestrzeni. Dlatego przebywając na danym terytorium i użytkując je, na krótszy lub dłuższy czas, uznaje je za w mniejszym lub większym stopniu własne i bezpieczne (Jałowiecki, Szczepański 2006). Proces ten odnosi się do mniejszych lub większych obszarów codziennych czynności. Na codzienny krajobraz składają się przestrzeń, materialne artefakty, ale także ludzie, których spotyka się na swej drodze. Z czasem wraz z narastaniem poczucia bezpieczeństwa i realizacji potrzeb biologicznych, w połączeniu ze wspomnieniami zapachów i dźwięków, i aktywności społecznych, rodzi się głębokie uczucie - przywiązanie do miejsca (Tuan 1987). Migranci jako mieszkańcy i użytkownicy pewnych obszarów uczestniczą w procesie przyswajania przestrzeni.

W tym kontekście warto przywołać pojęcie stawania się miejscowym (local) (Buhr 2015). Jest to praktyczna kategoria odnosząca się do „treningu”, która odwołuje się do nabywania przez migranta praktycznych umiejętności, pozwalających funkcjonować w danym kontekście. Dla migranta praktyczny zasób wiedzy obejmuje także to, których miejsc należy unikać. Zatem kategoria ta nie odnosi się do bycia akceptowanym przez innych mieszkańców. Perspektywa członków społeczeństwa przyjmującego czy większościowego nie jest tu brana pod uwagę. Imigranci mogą być przez nich kategoryzowani jako „obcy” mniej lub bardziej akceptowani bądź odrzucani.

Szczególnie użyteczny w analizie decyzji migracyjnych i wzorów osiedleńczych jest koncept sieci migracyjnej (migrants network) (Faist 2000, Portes i in. 1999, Vertovec, Cohen 1999). Analitycy migracji zwracają uwagę na rozwój przepływów migracyjnych (migration flows) i wzrost liczby potencjalnych migrantów. Sieci tworzone przez migrantów oferują wsparcie w znalezieniu zatrudnienia, zakwaterowania, redukują koszty ekonomiczne i psychiczne oraz ryzyko związane z międzynarodową mobilnością.

Inne użyteczne pojęcie to kapitał związany z konkretnym miejscem (location-specific capital) (DaVanzo1981). Pomimo rozwoju kanałów komunikacji (tanich połączeń telefonicznych, mediów społecznościowych) i środków transportu ludzie są wciąż powiązani z pewnymi terytoriami, a kapitał ludzki (w tym wykształcenie czy konkretne umiejętności) i społeczny (w tym krewni, przyjaciele, na których można polegać) nie jest łatwo transferowany $z$ jednego do drugiego miejsca. Zatem kapitał związany jest z konkretnym miejscem, a użyteczność zasobów dostępnych jednostkom jest terytorialnie ograniczona. W kontekście wzorów osiedleńczych rosnąca sieć krewnych i przyjaciół może kierować kolejnych migrantów do właściwych im miejsc zamieszkania. 


\section{Zwiększanie się populacji Polaków w Norwegii}

Norwegia w latach 80. XX. w. dała schronienie kilku tysiącom uchodźców politycznych z Polski, w latach 90. na podstawie umów zawartych między państwami przyjmowała sezonowych pracowników do pracy w rolnictwie. Badania przeprowadzone w 2006 r. w Oslo (głównie między pracownikami budowlanymi

Mapa 1.

Polscy imigranci oraz osoby urodzone w Norwegii, których rodzice pochodzą z Polski zamieszkujący w poszczególnych okręgach, 1 stycznia 2016 r.

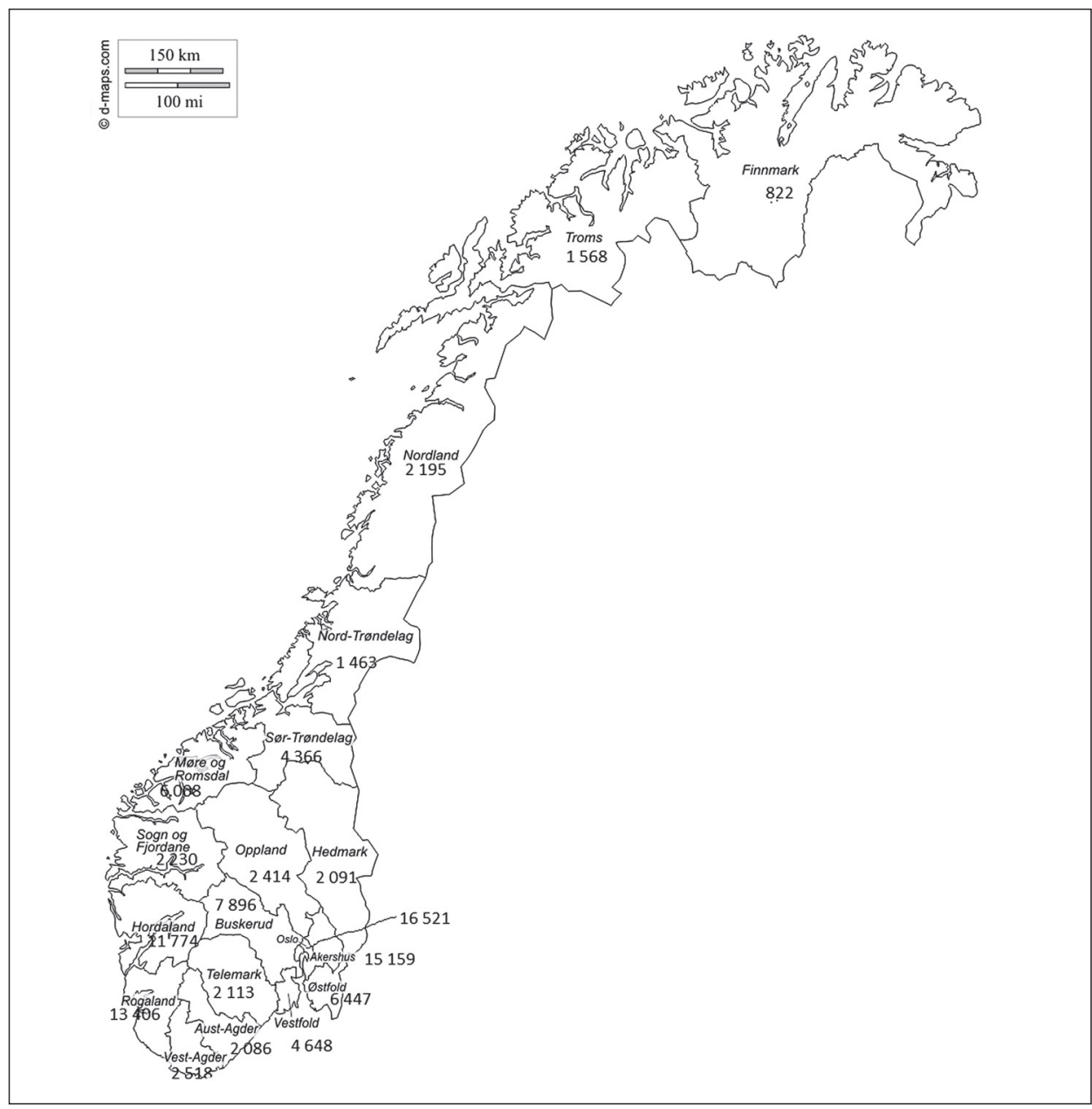

Źródło: Mapa Norwegii z podziałem na okręgi administracyjne, d-maps.com oraz obliczenia własne na podstawie baz danych Statistics Norway, Table 09817: Immigrants and Norwegian-born to immigrant parents, by immigration category, country background and percentages of the population. 
i sektora usług domowych) wykazały, że sieci odgrywały istotną rolę w przypadku migrantów pochodzących $\mathrm{z}$ województw zachodniopomorskiego i pomorskiego, a w przypadku migrantów pochodzących z województw małopolskiego i śląskiego najważniejsze były agencje pośrednictwa pracy (Napierała, Trevena 2010). Z kolei badania przeprowadzone w 2010 r. wykazały, że procent respondentów, którzy przed przyjazdem do Oslo znali kogoś, kto mieszkał w tym mieście lub jego okolicach, wzrósł w stosunku do 2006 r. Badacze doszli więc do wniosku, że wpływ sieci migracyjnej rośnie (Friberg i in. 2012: 158).

Od przystąpienia Polski do UE obserwujemy stały wzrost polskiej populacji w Norwegii. W 2004 r. liczyła ona mniej niż 10 tysięcy, a w 2016 już ponad 100 tys. Więcej niż połowa Polaków zamieszkuje w czterech okręgach (Oslo, Akershus, Rogaland, Hordaland), reszta rozsiana jest po całym kraju.

Tabela 1 .

Liczebność polskich imigrantów oraz osób urodzonych w Norwegii, których rodzice pochodzą z Polski w wybranych miastach, 1 stycznia 2016 r.

\begin{tabular}{|l|c|c|}
\hline \multicolumn{1}{|c|}{ Miasto } & Liczba Polaków & $\begin{array}{c}\text { Pozycja pod względem liczebności } \\
\text { wśród imigrantów w mieście }\end{array}$ \\
\hline Oslo & 16521 & 2 \\
\hline Bergen & 6726 & 1 \\
\hline Bærum & 3875 & 1 \\
\hline Stavanger & 3492 & 1 \\
\hline Sandnes & 2924 & 1 \\
\hline Trondheim & 2292 & 2 \\
\hline Drammen & 2037 & 1 \\
\hline Asker & 1874 & 1 \\
\hline Sarpsborg & 1416 & 2 \\
\hline Fredrikstad & 1314 & 1 \\
\hline Haugesund & 1272 & 1 \\
\hline Kristiansand & 1174 & 1 \\
\hline Ålesund & 1063 & 1 \\
\hline
\end{tabular}

Źródło: Obliczenia własne na podstawie baz danych Statistics Norway, Table 09817: Immigrants and Norwegian-born to immigrant parents, by immigration category, country background and percentages of the population. 
Geograficzne rozmieszczenie Polaków w Norwegii związane jest z zapotrzebowaniem na pracę. Znaczenie popytu na pracę - głównie mężczyzn - jako czynnika wzrostu liczby Polaków na przestrzeni ostatniej dekady odzwierciedla struktura demograficzna polskiej populacji w tym kraju' .

Wykres 1 .

Polscy imigranci oraz osoby urodzone w Norwegii, których rodzice pochodzą z Polski, stan na 1 stycznia $2016 \mathrm{r}$.

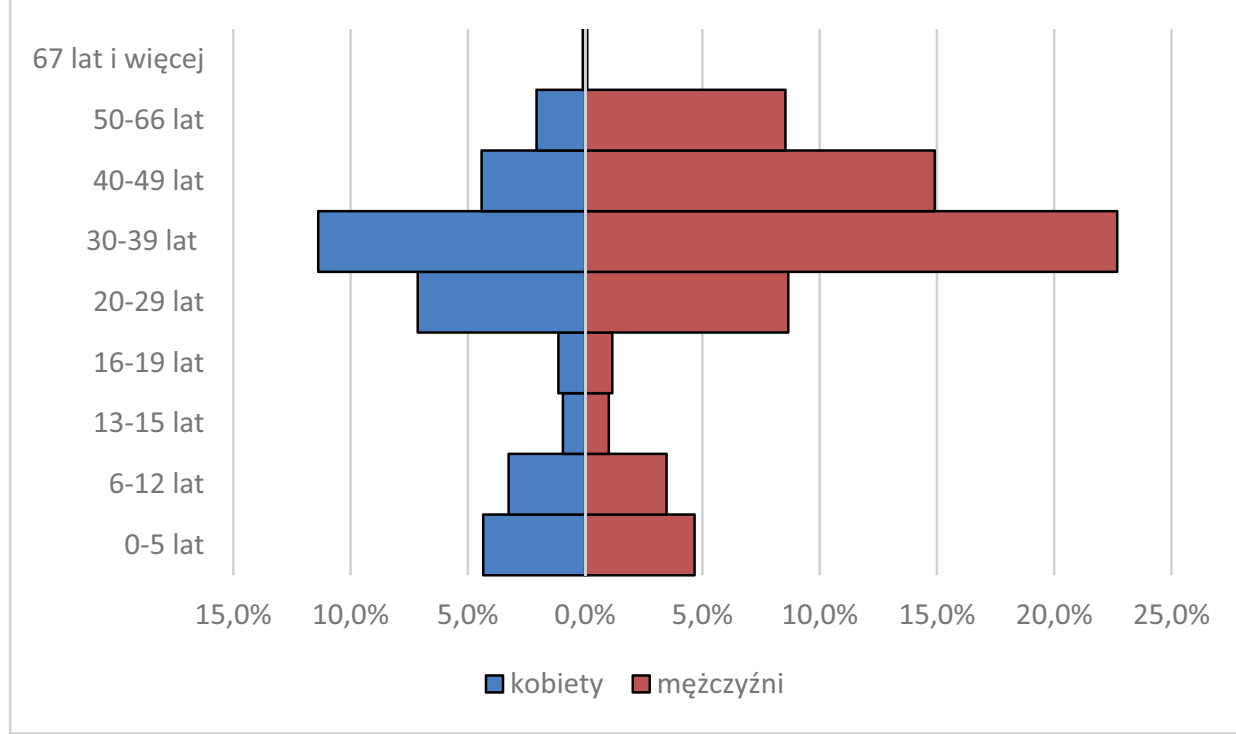

Źródło: Opracowanie własne na podstawie baz danych Statistics Norway, Table 05196: Population, by sex, age and citizenship.

\section{Spostrzeżenia na temat strategii osiedleńczych Polaków w Norwegii na podstawie badań projektu TRANSFAM}

\section{Wybór miejsca w Norwegii}

Spośród 24 rozmówców biorących udział w badaniach jakościowych tylko jeden zauważył, że w sąsiedztwie zaczyna się tworzyć polskie skupisko. Pozostałe wypowiedzi wskazują na to, że Polacy w danych miejscowościach nie tworzą odizolowanych społeczności czy sąsiedztw i są rozproszeni wśród innych niepolskich mieszkańców. Obecność rodaków, którzy nie są krewnymi lub znajomymi rozmówców,

\footnotetext{
${ }^{6}$ Więcej na ten temat w: Iglicka, Gmaj, Wierzejski $(2016,2018)$.
} 
sama w sobie nie stanowi zachęty do wyboru miejsca. Polacy przyjeżdżający do Norwegii nie są monolitem, co jest podkreślane w wywiadach. Wskazywane są także przykłady złych doświadczeń, które ograniczają chęć do nawiązywania kolejnych kontaktów z rodakami. Wspominana jest też rosnąca między Polakami konkurencja związana z tym, że część pracuje w szarej strefie za niższe stawki.

Kiedyś to było bardziej kontrolowane i nie mogli przyjechać kryminaliści, że tak powiem, czy złodzieje, a w tej chwili jest wszystko (...) mąż ma teraz takich cwaniaków [pracują $\mathrm{w}$ jego firmie].

(Kobieta 41 lat, od 11 lat w Norwegii, wliczając cyrkulowanie między Polską i Norwegią).

Pomagałam ze szkoła, z przedszkolem. I powiem Ci, że byliśmy maksymalnie wykorzystywani (...) Zaczęty się jakieś dziwne plotki, dogadywania (...) W tej chwili staramy się po prostu miło zachować, ale nie wchodzimy w bliższe relacje.

(Kobieta 47 lat, 24 lata w Norwegii).

Niemniej jednak waga kapitału społecznego związanego z konkretnym miejscem odgrywa istotną rolę. Rozmówcy przed swoim przyjazdem do Norwegii znali kogoś, kto tu pracował albo sami pomagali, angażując się w poszukiwanie pracy dla krewnych i znajomych.

R: Załatwiłem pracę szwagrowi, pierwsze. I on mieszkał trochę u nas. I później już poszedt na swoje, dostał prace $i$, $i$ wtedy przyjechała siostra $z$ dziećmi... Tak $\dot{z} e$, tak że to już trochę później byto, nie (...) Nadarzyła się okazja, miałem dobre relacje tam z takim szefem $z$ bytej firmy.

(Mężczyzna 36 lat, 8 lat w Norwegii).

R: On tu przyjechał tak samo [brat rozmówcy]. Też już tutaj ma rodzinę. Później ściqgnęliśmy trzeciego brata, później czwartego brata i jeden jedyny tylko w Polsce zostat i rodzice (...).

B: A znaliście się w Polsce, wcześniej [z żoną]?

R: Tak. I później w 2005 ona przyjechała na koniec tego roku. Tu zaszła w ciążę, urodzita tutaj syna i on chodzi teraz do szkoty.

(Mężczyzna 32 lata, 14 lat w Norwegii).

Tak więc migranci ekonomiczni stopniowo ściągali swoich krewnych - małżonków / partnerów i dzieci, rodzeństwo, a także dalszych krewnych. Dla części imigrantów obecność krewnych i znajomych jest bardzo pomocna w wyborze miejsca zamieszkania. Spostrzeżenie to dotyczy osób, które razem z pracą nie mają zagwarantowanego zakwaterowania. W innej sytuacji są specjaliści, jak np. pielęgniarki czy profesjonaliści w konkretnych obszarach sprowadzani przez norweskich pracodawców lub wyspecjalizowane agencje, oraz robotnicy, którym pracodawca organizuje zakwaterowanie $w$ formie hoteli robotniczych. Wracając jednak 
do tych pierwszych, warto zwrócić uwagę na pojawiające się w rozmowach relacje o trudnościach w znalezieniu mieszkania do wynajęcia. Przy tym nie jest to wyłącznie kwestia wysokich kosztów (czynsz i depozyt), ale także niechęci potencjalnych wynajmujących, gdy orientują się, że najemcami mają być migranci. Sieć migrancka pomaga trudności przezwyciężyć, a bywa, że przynajmniej przez pewien czas dzieli się mieszkanie z innymi Polakami. Ciekawą praktyką jest także przekazywanie mieszkań kolejnym rodakom, gdy wyprowadzają się wcześniejsi wynajmujący.

Nie mogliśmy sobie znaleźć domu do wynajęcia, bo ja np. pomimo tego, że intensywnie szukałam, wydzwaniałam zarówno do ogłoszeń z gazety, jak i też z Internetu, to jednak też nie mówiłam po norwesku, tylko po angielsku. To zawsze byto pytanie, a ską jestem. To było jakieś 2-3 miesiące, jak nic nie znalazłam i dopiero poprzez sąsiadkę, znajoma, udało nam się coś znaleźć, jakieś mieszkanie. Tak że na samym początku $z$ inna rodzina polska wynajmowaliśmy dom.

(Kobieta 40 lat, od 6 lat w Norwegii).

Czym kierowali się rozmówcy przy wyborze konkretnych miejsc zamieszkania? Ceną, połączeniami komunikacyjnymi (dojazd do szkoły, pracy własnym lub publicznym transportem) oraz bliskością lotniska. Przeprowadzka w ramach konkretnej miejscowości czy regionu związana jest $\mathrm{z}$ formowaniem się i cyklem życia rodziny. Rodziny z dziećmi potrzebują większych mieszkań. Wraz z rozpoczęciem nauki przez dzieci rodzice, przynajmniej na jakiś czas, starają się ograniczać swoją mobilność, aby nie zrywać więzów towarzyskich dzieci. Gdy jednak przeprowadzka jest konieczna, starają się, aby odbyło się to w jak najmniej bolesny dla dzieci sposób.

Jak już szukaliśmy tego mieszkania [kolejne mieszkanie w Norwegii], to mieliśmy taki cel założony, że ze względu na [imię córki], że miała już zaczynać szkołę, a wiedzieliśmy, że tutaj regionalnie dzieci idą do szkoły... to nie chcieliśmy, żeby zmieniała otoczenie.

(Kobieta, trzydziestoparolatka, od 7 lat w Norwegii).

\section{Stopniowe przyzwyczajanie się - „oswajanie Norwegii”}

Dorośli wykazują się zrozumieniem tego, że ich dzieci podczas codziennych czynności i poprzez codzienną rutynę budują poczucie bezpieczeństwa i przywiązują się do konkretnych miejsc i ludzi. Zresztą oni sami też dzielą to doświadczenie. I chociaż, jak wcześniej wspomniano, popyt na pracę kształtuje rozmieszczenie Polaków w Norwegii na poziomie makro, to na poziomie indywidualnym, szczególnie wśród osób, które kilka lat mieszkają w jednej miejscowości, zaobserwować można niechęć do przeprowadzki, nawet wtedy, gdy doświadczają one bezrobocia. Skąd ten opór? Można go tłumaczyć tym, że stają się oni „miejscowymi”, a początkowo abstrakcyjne terytorium staje się ich miejscem. 
RM: Mi się tu podoba i nie chcę zmieniać, bo mamy tu wszędzie blisko. Mam tu wszystko pod nosem. Fajnie tu też mieszkamy. (...)

RK: No, a tutaj to też mamy zorganizowane to życie. [imię syna] ma 3 razy $w$ tygodniu ma to...

RM: Ma taekwondo.

RK: Ma taekwondo. No, w soboty, to polska szkoła, co druga sobota.

RM: Jest też więcej tych tam dzieci więcej jakiś...

RK: To jest takie no, mają co robić, tak. To norweska szkoła, to lekcje.

RM: Kolegów ma [imię syna]. Ja też mam znajomych jakichś.

(Mężczyzna 38 lat, 7 lat w Norwegii; kobieta 37 lat, razem z synem dołączyła po ok. dwóch latach).

Rodzice angażują się w codzienność przedszkolną, szkolną, chodzenie na place zabaw, organizowanie zajęć sportowych, lekcje języka polskiego itp. Posłanie dzieci do placówek opiekuńczych i edukacyjnych oznacza kontakt z instytucjami, ale także z norweskimi rodzicami. Chociaż relacje zwykle są powierzchowne, przez niektórych odbierane nawet jako wymuszone, z czasem stają się rutyną bycia rodzicami w Norwegii. W tym kontekście rozmówcy najczęściej przywoływali przykład celebrowania urodzin, które kończą się zwykle kawą dla rodziców, a także szkolne i pozaszkolne imprezy sportowe. Stopniowo powiększa się krąg relacji zawodowych i towarzyskich. Dotyczy to kontaktów z Polakami, Norwegami i innymi imigrantami. Jednak bliskie relacje przyjacielskie $\mathrm{z}$ Norwegami, jeśli pojawiają się $\mathrm{w}$ trakcie wywiadów, to raczej w kontekście bycia odstępstwem od normy niż regułą.

RM: Mam jednego kolege Norwega, to jest ważna informacja. Jeden kolega prawdziwy, taki można powiedzieć najbliższy, Norweg.

RK: A reszta to raczej Polacy.

RM: Tacy znajomi i tak dalej. To jest jedyny, którego mam telefon, tak. Przytulamy się, jak się widzimy. Przychodzi, pomaga mi w norweskim trochę.

(Mężczyzna 38 lat, 7 lat w Norwegii; kobieta 37 lat, razem z synem dołączyła po ok. dwóch latach).

Do związków zawodowych należę. W pracy, u siebie, mam bardzo dobry kontakt (...). $Z$ tymi moim wspótpracownikami z mojego wydziału chodzimy, robimy sobie raz w miesiącu takie wyjścia do restauracji, no to same takie, to tak sobie gadamy, obmawiamy innych, że tak powiem ('smiech) tak to wyglada.

(Kobieta 41 lat, od 11 lat w Norwegii, włączając okres cyrkulowania między Polską a Norwegią).

Mamy mieszane towarzystwo, trochę towarzystwa polskiego, z którym się spotykamy, $i$ trochę norweskiego, $z$ którym też się spotykamy... Jak robimy $w$ domu, to staramy się mieszać te grupy. Zapraszamy obie grupy. W większości tych Polaków, których my znamy, to nie maja problemów, żeby rozmawiać po norwesku.

(Kobieta, trzydziestoparolatka, od 7 lat w Norwegii).

Z punktu widzenia procesu adaptacyjnego interesującą kwestię stanowi znajomość języka norweskiego. Polscy obywatele nie są niestety objęci programami 
integracyjnymi dostępnymi dla imigrantów spoza Europy, bo przebywają w Norwegii na mocy regulacji dotyczących swobodnego przepływu osób i dostępu do rynku pracy w ramach EOG. Materiał jakościowy dostarcza opisu starań podejmowanych przez Polaków w celu nauczenia się norweskiego. Jako jedną z trudności wskazuje się ograniczenie w dostępie do bezpłatnych kursów. Rozmówcy wskazywali korzystanie $\mathrm{z}$ różnych form dofinansowania, w tym ze strony związków zawodowych lub pracodawcy. Gdy mogą korzystać ze szkolenia zawodowego organizowanego przez NAV (Norweski Urząd Pracy), wybierają kursy językowe. Odkładają też pieniądze na przyszłą naukę. Matki opiekujące się w domu małymi dziećmi starają się uczyć języka w mniej lub bardziej zinstytucjonalizowany sposób. Dostęp do nauki języka jest zróżnicowany geograficznie. Jeden z rozmówców opowiadał o dwuletnim czasie oczekiwania na przyjęcie na kurs. W rozmowach pojawia się napięcie między Polakami a imigrantami spoza Europy związane z uprzywilejowaniem tych ostatnich.

Ja nie chodziłam do szkoły, nie dlatego, że mi się nie chciało. Ja nie miałam możliwości, nie było miejsc (...). Teraz jestem w szkole. Jakby pan przyszedt na przerwie, to ludzie $w$ wieku 50-60 lat, czarnoskórzy ucza się języka (...) oni mają za darmo. NAV, gmina za to placi (...). Dla nas nie ma miejsc. Dla nas nie moga utworzyć grupy, gdzie chcielibyśmy. A później mówi «Ile mieszkasz lat? Osiem? I ty jeszcze norweskiego nie znasz?!» I to jest strasznie przykre. To jest bardzo przykre, że oni by chcieli, żebyśmy się nauczyli tego języka, a nie daja nam możliwości.

(Kobieta, trzydziestoparolatka, od 9 lat w Norwegii).

$\mathrm{Na}$ zakończenie omawiania kwestii znajomości języka norweskiego zwróćmy uwagę, że nawet ci rozmówcy, którzy zdali państwowy egzamin o najwyższej trudności, po latach mieszkania w Norwegii nie czują, aby ich umiejętności pozwoliły „wtopić się” w społeczeństwo norweskie, wciąż rozpoznawani są jako cudzoziemcy.

Mieszkamy w Norwegii na chwile obecną 6 lat, ale nie mogę powiedzieć, że dobrze znam język, jeśli chodzi o wymowę. Bo rozumiem dobrze, czytam literaturę, zdaję egzaminy, pisze wypracowania. To, że znałam angielski, to dużo mi pomogło. Mą̇ był na kursie i też mówi po norwesku, ale ten jego język jest bardziej techniczny - to, co musi w pracy. (Kobieta 40 lat, od 6 lat w Norwegii).

Znajomość języka pomaga w uzyskaniu lepszej pozycji na rynku pracy. Badanie ankietowe pozwala dostrzec zależność pomiędzy poziomem znajomości języka norweskiego a pozycją na rynku pracy, wyznaczoną stałą pracą na pełnym etacie. Udział procentowy osób zatrudnionych na stałe na pełnym etacie wzrasta wraz z poziomem zaawansowania znajomości języka ${ }^{7}$.

${ }^{7}$ Na poziomie istotności 0,05 można odrzucić hipotezę o niezależności zmiennych. Zależność jednak nie jest silna, skorygowany współczynnik kontyngencji C-Pearsona wynosi 0,34. 
Tabela 2 .

Poziom znajomości języka norweskiego a typ zatrudnienia (rozkład procentowy)

\begin{tabular}{|c|c|c|c|c|c|}
\hline & $\begin{array}{c}\text { Brak } \\
\text { znajomości } \\
\text { języka }\end{array}$ & $\begin{array}{c}\text { Poziom } \\
\text { początkujący } \\
\text { (umiejętność } \\
\text { komunikacji } \\
\text { w prostych } \\
\text { sytuacjach, } \\
\text { jak zakupy, } \\
\text { powitania, } \\
\text { zapytania } \\
\text { o drogę, } \\
\text { odbycie } \\
\text { prostej } \\
\text { rozmowy) }\end{array}$ & $\begin{array}{c}\text { Poziom } \\
\text { podstawowy } \\
\text { (umiejętność } \\
\text { prowadzenia } \\
\text { rozmowy } \\
\text { na tematy } \\
\text { codzienne, } \\
\text { rozumienie } \\
\text { poleceń } \\
\text { w pracy) }\end{array}$ & $\begin{array}{c}\text { Poziom średnio } \\
\text { zaawansowany } \\
\text { (umiejętność } \\
\text { komunikacji } \\
\text { w różnych } \\
\text { sytuacjach, } \\
\text { ale jeszcze brak } \\
\text { swobodnego } \\
\text { porozumie- } \\
\text { wania się) }\end{array}$ & $\begin{array}{c}\text { Poziom } \\
\text { zaawansowany / } \\
\text { biegła } \\
\text { znajomość } \\
\text { (swobodna } \\
\text { komunikacja } \\
\text { w pracy, } \\
\text { urzędzie, } \\
\text { w kontaktach } \\
\text { towarzyskich) }\end{array}$ \\
\hline $\begin{array}{l}\text { Inna forma } \\
\text { zatrudnienia }\end{array}$ & 66 & 45 & 32 & 29 & 15 \\
\hline $\begin{array}{l}\text { Stała praca } \\
\text { na pełnym } \\
\text { etacie }\end{array}$ & 34 & 55 & 68 & 71 & 85 \\
\hline Razem & 100 & 100 & 100 & 100 & 100 \\
\hline
\end{tabular}

Źródło: Ankieta internetowa przeprowadzona w ramach projektu TRANSFAM

Warto zauważyć, że rozmówcy pod względem religijności stanowili zróżnicowaną próbę. W życiu tych, dla których religia stanowi istotny element, znalezienie kościoła, w którym odprawiane są msze po polsku, jest jednym z ważnych etapów przyswajania przestrzeni. Istotny jest nie tyle konkretny budynek, w którym ludzie mogą odtwarzać „kawałek Polski” poprzez zaangażowanie się w obrządek religijny - co oczywiście jest ważne z punktu widzenia budowania poczucia bezpieczeństwa i przyswajania przestrzeni, ile religijne rytuały, regularne wizyty w niedziele i święta, uczestnictwo w katechezie czy innych formach aktywności w parafii, organizujące życie imigrantów w powtarzalne sekwencje, wprowadzające w ich życie rutynę, która przyczynia się wzmocnienia poczucia bezpieczeństwa i przewidywalności.

Wcześniej mąż tam chodził po norwesku. Ewentualnie msza była po polsku w Oslo, w Olafie. Potem zrobili raz w miesiącu, ojciec [imię] chyba wtedy jeszcze przyjeżdżat przynajmniej do [nazwa miejscowości], to już ja pamiętam, no to już tak brakowało... no raz w miesiacu czemu tylko (...). Teraz już trzeci rok czy, czy nawet więcej mamy, że mamy co niedzielę mszę (...) od miesięcy... dwóch czy trzech, że jest na dziewiąta i na 
czternasta, czyli już dwa razy w niedzielę, więc po prostu, ale to dlatego, że tylu Polaków przyjechało i (...) no, no bo, i na rano jest pełen kościót i na popołudnie.

(Kobieta 30 lat, od 7 lat w Norwegii).

Kościoły z nabożeństwami po polsku wpisują się w lokalny krajobraz. Poprzez nie migranci zaznaczają swoją obecność w Norwegii i w konkretnych miejscowościach. Podobnie poprzez informacje w języku polskim na oficjalnej stronie Kościoła Rzymskokatolickiego w Norwegii zaznaczają swoją obecność w wirtualnej, a jednak umocowanej geograficznie i językowo, przestrzeni. Warto w tym miejscu zauważyć, że katolicy są zróżnicowaną etnicznie mniejszością wyznaniową. Duszpasterstwo polskie jest częścią Kościoła Rzymskokatolickiego w Norwegii. Chociaż z różną częstotliwością, to praktycznie w każdej parafii organizowane są msze w języku polskim (Burkiewicz 2015). Na portalu Moja Norwegia znajduje się lista 44 takich miejsc (stan na 8 lutego 2015 roku). Ich rozkład pokrywa się obecnością Polaków, a także - szerzej - z gęstością zaludnienia Norwegii. Kościoły odgrywają także rolę w życiu mniej religijnych osób, które odwiedzają je tylko na Wielkanoc czy Boże Narodzenie, żeby odczuć atmosferę świąt znaną z Polski. Rozmówcy ci odtwarzają $\mathrm{w}$ nowym miejscu fragment polskiej obyczajowości, przy czym nie wiąże się to z przeżyciami natury religijnej. W powszechnej świadomości zgromadzenia w miejscach sakralnych służą również wymianie informacji na temat możliwości podjęcia pracy czy znalezienia mieszkania, mają zatem także bardzo pragmatyczny charakter.

Wraz ze wzrostem liczby Polaków (Tabela 3.), rozwijają się także tzw. etniczne usługi. Część rozmówców wspomina o korzystaniu z usług polskich fryzjerek, kosmetyczek, mechaników samochodowych pracujących w Norwegii. Usługi te cieszą się też zainteresowaniem innych imigrantów, co można $\mathrm{z}$ kolei łączyć z ich niższą ceną niż ta wyznaczana przez usługodawców Norwegów. Część rozmówców wskazuje także, że stara się korzystać z usług polskich pielęgniarek i lekarzy. Niektórzy powołują się na własne złe doświadczenia, inni na generalny brak zaufania do „obcych” lekarzy czy szerzej norweskiej służby zdrowia, która ich zdaniem bagatelizuje sytuacje, do jakich w Polsce podchodzi się poważniej: „człowiek przychodzi do lekarza, wydaje mu się że jest ciężko chory, a otrzymuje tak zwaną polopirynę, paracetamol na wszystko" (mężczyzna 53 lata, od 7 lat w Norwegii). Rozmówcy wymieniają także barierę językową, która nie pozwala na nawiązanie kontaktu, często w intymnych lub trudnych kwestiach. Korzystanie z polskich usług sprawia, że migranci mogą poczuć się „jak w domu”. W odróżnieniu od Wielkiej Brytanii czy Irlandii w Norwegii nie ma jednak wielu miejsc, w których można kupić polskie jedzenie. Polskie produkty można odnaleźć w sklepach z żywnością azjatycką czy z różnych stron świata. Lista typowych polskich sklepów jest krótka (patrz: portal Moja Norwegia). Spowodowane to jest tym, że Norwegia nie ma umowy z Unią Europejską w sprawie wolnego handlu produktami spożywczymi. Nałożone jest na nie wysokie cło i dodatkowe opłaty związane ze składem konkretnych produktów (np. zawartością cukru). 
Tabela 3

Polscy imigranci i osoby urodzone w Norwegii, których rodzice pochodzą z Polski (stan na 1 stycznia roku określonego w pierwszym wierszu tabeli)

\begin{tabular}{|c|c|c|c|c|c|c|c|}
\hline & 2004 & 2005 & 2006 & 2007 & 2008 & 2009 & 2010 \\
\hline Mężczyźni & 2718 & 3711 & 5995 & 11442 & 21583 & 29971 & 33949 \\
\hline \multirow[t]{2}{*}{ Kobiety } & 4872 & 5222 & 5869 & 7392 & 10486 & 14511 & 18176 \\
\hline & 2011 & 2012 & 2013 & 2014 & 2015 & 2016 & \\
\hline Mężczyźni & 38792 & 46790 & 53778 & 58883 & 63627 & 67014 & \\
\hline Kobiety & 21818 & 25313 & 28823 & 32296 & 35797 & 38711 & \\
\hline
\end{tabular}

Źródło: Opracowanie własne na podstawie baz danych Statistics Norway, Table 05184: Immigrants, by sex and country background Statistics Norway

\section{Gdzie jest „dom”?}

W którym z krajów migranci czują się jak w domu? Pytanie takie znalazło się w internetowej ankiecie. Odpowiedzi respondentów rozłożyły się następująco: w Norwegii 38 proc., w Polsce 27 proc., w Polsce i Norwegii 33 proc., w innym miejscu 2 proc. Analizując materiał jakościowy, widzimy, jak przez zaangażowanie w codzienne aktywności część rozmówców stopniowo zadomawia się w Norwegii. Inni, pomimo lat spędzonych w Norwegii, jako dom wciąż traktują Polskę, a w Norwegii czują się jak „goście”. Na szczególna uwagę zasługuje trzecia kategoria związku, którą określić można jako podwójną orientację (dual orientation) (Vertovec 2008), charakterystyczną dla migrantów transnarodowych (transnational migrants). Dotyczy ona sytuacji, w której imigranci adaptują się i czują silny związek z krajem imigracji, a jednocześnie utrzymują silne związki uczuciowe i materialne $\mathrm{z}$ krajem pochodzenia. Nawet w obrębie jednej rodziny dostrzec można różne podejścia.

RK: Jak jadę do Polski, to jadę do domu.

B: A jak Pani wraca $z$ Polski?

RK: To wracam do Norwegii.

RM: Ja to już różnie, nie raz mówię, że tu [do Norwegii] wracam do domu. Na przykład syn, jak jechaliśmy samochodem ostatnio i wjechaliśmy do Szwecji, i tak już zjechaliśmy z promu, jechaliśmy kawałek i syn: «o Szwecja, to już tylko kawałek, to już prawie jak $w$ domu». No on się tutaj czuje bezpiecznie.

RK: Gdzie oni [dorosłe dzieci] mieszkają na wynajętym. A ja myślałam, że mi się zmieni, jak myśmy to kupili [mieszkanie w Norwegii]. Myśle sobie, a może mi się to zmieni, bo czuje, że to moje... Ale nie. Nie mam czegoś takiego.

(Mężczyzna 43 i kobieta 41 lat, od 11 lat w Norwegii, wliczając lata cyrkulowania między Polską i Norwegią). 
Analizując materiał jakościowy, zauważa się pewien wzór: gdy pozwala na to sytuacja ekonomiczna rodziny, zamiast wynajmowania mieszkania decyduje się ona na kupno nieruchomości, co wiąże się z wzięciem kredytu. Mogą sobie na to pozwolić osoby, które osiągnęły pewną stabilność zatrudnienia. Kupno nieruchomości, a szczególnie kredyt, może przywiązać, przynajmniej na jakiś czas, Polaków do Norwegii. Część rozmówców wspomina o tym, że ze względu na zmieniające się potrzeby rodziny ma już za sobą sprzedaż mieszkania, czy też planuje sprzedaż, gdy dzieci ukończą szkoły. Niestety nie ma statystyk dotyczących posiadania przez Polaków nieruchomości, które mogłyby opisać sytuację polskiej populacji w Norwegii. Ciekawe są jednak wyniki ankiety internetowej, 37 proc. respondentów wskazało, że posiada w Norwegii nieruchomość.

\section{Plany związane z pozostaniem na stałe w Norwegii}

Kwestia planów związanych z pozostaniem na stałe poruszona została w ankiecie internetowej. Rozkład odpowiedzi przedstawia się następująco: połowa respondentów planuje pozostanie w Norwegii na stałe, 15 proc. nie ma takich planów, a 35 proc. nie podjęło jeszcze decyzji. Okazało się, że nie ma związku pomiędzy płcią respondentów a ich planami ${ }^{8}$. Także wykształcenie i posiadanie lub nieposiadanie dzieci przez respondentów nie wpływało na rozkład wyników 9 . Zaobserwowano bardzo słaby związek pomiędzy planami osiedleńczymi a wiekiem respondentó $w^{10}$ i rokiem ich przyjazdu do Norwegii ${ }^{11}$, można więc skonkludować, że te czynniki także nie wpływały na rozkład odpowiedzi.

Tabela 4. przedstawia powody, dla których respondenci chcieli zostać w Norwegii na stałe. Mogli wybrać więcej niż jeden argument z gotowej listy. Wyniki pokazują, że lepsze warunki pracy, a więc czynnik ekonomiczny, to najczęstszy powód, podało go prawie 2/3 pytanych. Następne w kolejności są: brak perspektyw w Polsce oraz wyższy standard życia w Norwegii (każdy wymieniony przez połowę pytanych). Warto jest także zwrócić uwagę, że prawie co czwarta osoba wymieniła to, że dzieci rozpoczęły edukację w Norwegii, co wiąże się z cyklem rozwoju rodziny.

W badaniach jakościowych wśród argumentów za pozostaniem w Norwegii pojawia się ponadto przekonanie o większych niż w Polsce szansach, które będą miały dzieci. Analizując migracje z punktu widzenia różnych faz cyklu życia (life-course

${ }^{8}$ Na poziomie istotności 0,05 nie ma podstaw do odrzucenia hipotezy o niezależności zmiennych.

9 W przypadku poziomu wykształcenia oraz posiadania lub nieposiadania dzieci na poziomie istotności 0,05 nie ma podstaw do odrzucenia hipotezy o niezależności zmiennych.

${ }^{10}$ Są podstawy do odrzucenia hipotezy o niezależności zmiennych na poziomie istotności 0,05 . Z tym, że współczynnik kontyngencji C Pearsona wynosi 0,15 .

${ }^{11}$ Są podstawy do odrzucenia hipotezy o niezależności zmiennych na poziomie istotności 0,05 . Z tym, że współczynnik kontyngencji C Pearsona wynosi 0,22. 
perspective), zauważyć trzeba, że „migranci koncentrują się na krótkookresowych korzyściach jak wyższe zarobki czy lepszy standard życia, ale motywowani są także lepszymi perspektywami na przyszłość dla siebie, swoich partnerów i osób pozostających na ich utrzymaniu”" (King i in. 2006: 245).

Tabela 4.

Najważniejsze powody, dla których respondenci $\left(540\right.$ osób $\left.{ }^{12}\right)$ chcieliby się osiedlić w Norwegii

\begin{tabular}{|l|c|}
\hline \multicolumn{1}{|c|}{ Powód } & $\begin{array}{c}\text { Procent respondentów, } \\
\text { którzy wybrali dany powód }\end{array}$ \\
\hline $\begin{array}{l}\text { Odpowiada mi kulturowa / religijna / społeczna atmosfera } \\
\text { w Norwegii }\end{array}$ & 19 \\
\hline $\begin{array}{l}\text { Relacje z rodziną w Polsce nie przetrwały (nie mam do kogo } \\
\text { wracać) }\end{array}$ & 2 \\
\hline Dzieci rozpoczęły edukację w Norwegii & 24 \\
\hline $\begin{array}{l}\text { Lepsze warunki pracy w Norwegii: wyższe zarobki, stały kon- } \\
\text { trakt itd. }\end{array}$ & 67 \\
\hline Brak perspektyw w Polsce & 51 \\
\hline Wyższy standard życia w Norwegii & 50 \\
\hline $\begin{array}{l}\text { Lepszy dostęp do pomocy ze strony państwa w Norwegii } \\
\text { (świadczenia społeczne, rodzinne) }\end{array}$ & 14 \\
\hline $\begin{array}{l}\text { Osoby z mojej rodziny chcą mieszkać w Norwegii (np. part- } \\
\text { ner / partnerka, dzieci) }\end{array}$ & 11 \\
\hline Inne & 2 \\
\hline
\end{tabular}

Źródło: Ankieta internetowa przeprowadzona w ramach projektu TRANSFAM

Ankieta internetowa dotyczy deklaracji i planów, które mogą się zmienić. Dane statystyczne dotyczące długości pobytu wskazują na jego wydłużanie. Od 2010 do początku 2016 r. liczba Polaków mieszkających w Norwegii przez okres 6 lat lub dłuższy wzrosła z sześciu do prawie 43 tys. (Tabela 5.). Osoby te stanowią około 40 proc. całkowitej liczby polskich imigrantów i osób urodzonych w Norwegii, których rodzice pochodzą z Polski. Należy również podkreślić, że wzrasta liczba polskich dzieci (od 0 do15 lat). Na początku 2016 r. było ich 17,5 tys., co oznacza,

12 Osoby, które planują pozostanie w Norwegii na stałe, oraz te, które nie podjęły jeszcze decyzji, $\mathrm{z}$ pominięciem tych, które odrzuciły możliwość zostania w tym kraju na stałe. 
że ich liczba wzrosła dwuipółkrotnie w stosunku do 2010 r. (Tabela 6.). Do wzrostu przyczyniają się nie tylko przyjazdy, ale także to, że Polki rodzą dzieci w Norwegii (Tabela 7.).

Tabela 5 .

Polacy mieszkający w Norwegii 6 lat i więcej (stan na 1 stycznia roku określonego w pierwszym wierszu tabeli)

\begin{tabular}{|c|c|c|c|c|c|c|c|}
\hline Rok & 2010 & 2011 & 2012 & 2013 & 2014 & 2015 & 2016 \\
\hline & 6262 & 7435 & 9993 & 15547 & 25639 & 35516 & 42699 \\
\hline
\end{tabular}

Źródło: Opracowanie własne na podstawie baz danych Statistics Norway, Table10598: Immigrants, by country background and duration of stay $(\mathrm{F})$.

Tabela 6 .

Liczba dzieci (polscy obywatele, do 15 roku życia, stan na 1 stycznia roku określonego w pierwszym wierszu tabeli)

\begin{tabular}{|c|c|c|c|c|c|c|c|}
\hline Rok & 2010 & 2011 & 2012 & 2013 & 2014 & 2015 & 2016 \\
\hline & 7137 & 8992 & 10738 & 12560 & 14420 & 16078 & 17642 \\
\hline
\end{tabular}

Źródło: Opracowanie własne na podstawie baz danych Statistics Norway, Table 05196: Population, by sex, age and citizenship.

Tabela 7 .

Urodzenia żywe wśród matek urodzonych w Polsce ${ }^{13}$

\begin{tabular}{|c|c|c|c|c|c|c|}
\hline Rok & 2011 & 2012 & 2013 & 2014 & 2015 & 2016 \\
\hline & 1160 & 1265 & 1385 & 1488 & 1616 & 1478 \\
\hline
\end{tabular}

Źródło: Opracowanie własne na podstawie baz danych Statistics Norway, Table 10518: Immigrants and Norwegian-born to immigrant parents. Increase in population, by country background.

Niewielkim zainteresowaniem wśród Polaków cieszy się obywatelstwo norweskie. Tabela 8. przedstawia liczbę naturalizacji w latach 2004-2015. Należy jednak wspomnieć, że po 5 latach przebywania w Norwegii obywatele EOG, którego częścią jest UE, nabywają prawo do stałego pobytu, a z nim prawo do zamieszkania i pracy w Norwegii na stałe oraz dodatkową ochronę przed wydaleniem

${ }^{13} \mathrm{~W}$ przypadku, gdy rodzice pochodzą z różnych krajów, pod uwagę bierze się kraj pochodzenia matki, gdy ojciec dziecka jest Norwegiem urodzenie nie jest uwzględnione w tej statystyce. 
(UDI ${ }^{14}$, oficjalna strona). Zatem obywatelstwo norweskie traci na atrakcyjności ${ }^{15}$. Obszarem przyszłych badań może być kwestia partycypacji polskich migrantów w norweskim systemie politycznym, szczególnie w kontekście ogólnych cech życia politycznego w Polsce ${ }^{16}$.

Tabela 8 .

Naturalizacja osób z wcześniejszym polskim obywatelstwem

\begin{tabular}{|l|l|l|l|l|l|l|l|l|l|l|l|l|}
\hline Rok & 2004 & 2005 & 2006 & 2007 & 2008 & 2009 & 2010 & 2011 & 2012 & 2013 & 2014 & 2015 \\
\hline liczba osób & 171 & 126 & 112 & 31 & 74 & 77 & 50 & 80 & 138 & 166 & 324 & 251 \\
\hline
\end{tabular}

Źródło: Opracowanie własne na podstawie baz danych Statistics Norway, Table 04767: Naturalisations, by sex, age and earlier citizenship.

Migracje Polaków do Norwegii wpisują się w model migracji łańcuchowych (chain migration) analizujący mobilność w kontekście stadiów migracji pionierskich, zarobkowych i rodzinnych (MacDonald, MacDonald 1964). Materiał jakościowy dostarcza opisu tego, jak migranci ekonomiczni stopniowo ściągają swoich krewnych czy zakładają w Norwegii rodziny. Dopatrzyć się można analogii z sytuacją części polskich migrantów w Wielkiej Brytanii, a mianowicie $\mathrm{z}$ fenomenem emigracyjnego pioniera - głównie męża lub ojca - który przybywa jako pierwszy, a następnie ściąga żonę i dzieci (White 2009). Od 2006 r. polscy obywatele stanowią najliczniejszą grupę cudzoziemców wskazujących względy rodzinne jako przyczynę przyjazdu do Norwegii (Thorud i in. 2014). Za wyjątkiem 2009 r., który z powodu kryzysu gospodarczego, jaki dotknął kraje skandynawskie, był szczególnie trudny dla polskich rodzin w Norwegii, obserwujemy wzrost liczby wskazań na łączenie rodziny. O potencjalnych możliwościach łączenia rodzin może świadczyć dysproporcja pomiędzy kobietami i mężczyznami pozostającymi w związkach małżeńskich. W 2016 r. wśród polskich obywateli w Norwegii było 15139 mężatek i 34560 żonatych mężczyzn ${ }^{17}$. W strukturze demograficznej polskiej populacji w Norwegii (Wykres 1.) widoczna jest dominacja mężczyzn w wieku 20-66 lat, przy czym szczególnie liczna jest kategoria trzydziestolatków i czterdziestolatków.

${ }^{14}$ UDI to skrót norweskiej nazwy dyrektoriatu do spraw imigracji: Utlendingsdirektoratet.

15 Od 1 stycznia 2017 r. przy staraniu się o obywatelstwo będzie obowiązywał wymóg zdania egzaminu z języka (norweskiego lub sami) na poziomie A2 oraz z wiedzy obywatelskiej (UDI, oficjalna strona).

${ }^{16}$ Współczynnik identyfikacji z partami politycznymi jest niski, a osoby, które nigdy nie głosują, stanowią 20\% uprawnionych (Raciborski 2011, s. 134-136). W ostatnich wyborach parlamentarnych (2015) głosowała nieco ponad połowa uprawnionych obywateli (Obwieszczenie Państwowej Komisji Wyborczej z dnia 27 października 2015 r.).

${ }_{17}$ Obliczenia własne na podstawie baz danych Statistics Norway, Table 05328: Population, by sex, marital status and citizenship. 
Wśród dwudziestolatków dysproporcja między płciami maleje, a wśród osób poniżej dwudziestego roku życia zostaje zniesiona. Liczba dzieci do 12 roku życia znacznie przewyższa liczbę pozostałych nastolatków, co także może wskazywać na postępujący proces łączenia i zakładania przez Polaków rodzin w Norwegii.

Tabela 9 .

Migracje rodzinne z Polski do Norwegii, 2004-2013.

(Podstawa podawana przy nowych zezwoleniach na pobyt)

\begin{tabular}{|c|c|c|c|c|c|c|c|c|c|c|}
\hline Rok & 2004 & 2005 & 2006 & 2007 & 2008 & 2009 & 2010 & 2011 & 2012 & 2013 \\
\hline & 390 & 748 & 1702 & 3292 & 4423 & 2773 & 4612 & 4376 & 4516 & 4687 \\
\hline
\end{tabular}

Źródło: UDI za Thorud i in. (2014: 16).

W prowadzonych w Europie analizach migracji bada się trajektorie migracji rodzinnych, przy czym obowiązuje w nich głównie paradygmat „rodziny nuklearnej” (King i in. 2006). Na podstawie badań jakościowych przeprowadzonych w projekcie TRANSFAM także opisać można ścieżki, które doprowadziły imigrantów do etapu, w którym widzą przyszłość swoich rodzin w Norwegii. Typowa migracja osiedleńcza (tzn. planowana migracja całej rodziny w celu zmiany miejsca do życia) wydaje się raczej wyjątkową sytuacją. Nieplanowane i stopniowe osiedlanie się całej rodziny wydaje się bardziej typowym wzorem. Można go opisać w następujący sposób: jedno z małżonków (przeważnie mężczyzna) ma możliwość podjęcia pracy w Norwegii. Ma to być czasowe rozwiązanie. Jednakże separacja okazuje się zbyt bolesnym doświadczeniem, dlatego z czasem dołączają inni członkowie rodziny, też „na jakiś czas”. Pomimo braku początkowych planów osiedleńczych przedłużają swój pobyt, pomagają w migracji innym Polakom. Z czasem rodzą się dzieci albo osiągają wiek pozwalający na posłanie ich do norweskich przedszkoli i szkół. I tak osoby, które początkowo określić można było jako migrantów cyrkulacyjnych albo krótkookresowych, zakorzeniają się w Norwegii. Podobnie rodziny, które początkowo zdecydowały się na wspólny wyjazd tylko na pewien czas w związku z możliwościami zatrudnienia jednego z małżonków, wraz z przedłużającym się kontraktem czy znalezieniem stałego zatrudnienia ostatecznie zapuszczają korzenie w Norwegii. Tutaj swoją przyszłość ostatecznie budują także migranci, którzy przyjechali bez zobowiązań rodzinnych, ale w pewnym momencie właśnie tu założyli rodziny.

Podsumowując, wyniki projektu TRANSFAM są zgodne z wnioskami płynącymi z wcześniejszych badań, a mianowicie z konstatacją, że procesy migracyjne i adaptację polskich migrantów w Norwegii lepiej analizować jest w kontekście różnych stadiów procesu migracyjnego niż różnych kategorii migrantów (Friberg 2012). Jon Horgen Friberg wyróżnił trzy takie fazy. Pierwszą z nich charakteryzują plany powrotu do domu w bliskiej przyszłości. Drugą - powtarzające się podróże 
między Norwegią i Polską, przy czym ta przedłużająca się tymczasowość wiąże się z możliwościami podjęcia pracy. Ostatnia faza - osiedlenie - wiąże się z przeniesieniem gospodarstwa domowego do Norwegii, czyli ze sprowadzeniem rodziny. Migranci kształtują swoje strategie w zależności od bieżących okoliczności, różnych faz cyklu życia, a ich początkowe plany ulegają zmianie. Chociaż migranci nie muszą przejść całego cyklu, zdarza się, że osoby, które planowały jednorazową akumulację kapitału, zaczynają cyrkulować pomiędzy Polską i Norwegią, a w pewnym momencie mogą przedłużyć swój pobyt w Norwegii i sprowadzić członków rodziny.

\section{Podsumowanie}

Wyniki badań przeprowadzonych w projekcie TRANSFAM - jakościowe i ilościowe - wskazują, że w Norwegii kluczową rolę w strategiach osiedleńczych polskich migrantów i ich rodzin odgrywa czynnik ekonomiczny. Tutaj polskie rodziny odnajdują poczucie bezpieczeństwa ekonomicznego.

RK: Poczucie bezpieczeństwa.

RM: Spokój

RK: Jak chodzę do tej pracy, tak, wiem, że dostane wypłatę. Wiem, na co mogę przeznaczyć tę wyptatę. Wiem, że na rachunki mnie stać. Będzie mnie stać, żeby nie wiem jaką́ fanaberię swoją spetnić.

RM: Na normalne życie nas stać.

(Mężczyzna 38 lat, 7 lat w Norwegii; kobieta, 37 lat, razem z synem dołączyła po dwóch latach).

Na podstawie wyników badań jakościowych można stwierdzić, że w Norwegii łatwiej jest osiągnąć równowagę między życiem rodzinnym i zawodowym, co również stanowi czynnik zachęcający do pozostania w tym kraju.

Tutaj jest o tyle łatwiej jest być rodzicem $w$ Norwegii, że pomimo tego, że pracujemy oboje, pracujemy na petnym etacie, nie wiem, to życie jest jakoś mniej stresowe, dlatego jest może łatwiej. W Polsce tak, jak patrze na niektórych, to jestem w szoku, że tam nikt na nic nie ma czasu... więc na pewno jest to jakieś utrudnienie przy byciu rodzicem, jeżeli człowiek jest zawsze zabiegany, wiecznie zestresowany.

(Kobieta, trzydzieści kilka lat, od 6 lat w Norwegii).

Znacząca większość respondentów ankiety internetowej TRANSFAM (85 proc.) oceniła wynikającą z imigracji sytuację swojej rodziny jako co najmniej dobrą. Blisko 15 proc. miało problem $\mathrm{z}$ diagnozą i tylko mniej niż jeden proc. oceniło ją jako złą lub bardzo złą. Wyższy standard życia podawany jest przez połowę pytanych jako powód, dla którego mogliby osiąść w Norwegii na stałe. Co więcej, 
w wywiadach biograficznych i ustrukturyzowanych przyszłość dzieci i samych migrantów w Norwegii przedstawiana jest jako dająca większe szanse i możliwości niż życie w Polsce.

Celem artykułu jest przybliżenie mechanizmów, przez które zachodzi adaptacja polskich migrantów do życia w Norwegii oraz odpowiedź na pytanie, czy ich pobyt nabiera długoterminowego charakteru. Materiał zebrany w wywiadach biograficznych i ustrukturyzowanych pokazuje, jak stopniowo Polacy uczą się życia w Norwegii i bez względu na początkowe plany przedłużają swój pobyt w tym kraju. „Oswajanie” Norwegii odbywa się poprzez codzienną rutynę związaną z mieszkaniem i pracą w tym kraju. Przy tym istotną część procesu przystosowawczego stanowią aktywności związane $\mathrm{z}$ funkcjonowaniem rodziny, w tym $\mathrm{z}$ rodzicielstwem. Początkowa obca przestrzeń dla części Polaków staje się domem. Dla innych, pomimo kilku lat spędzonych w Norwegii, domem jest wciąż Polska, a w Norwegii czują się jak „goście”. Są też tacy, którzy czują silny związek z Norwegią, a jednocześnie utrzymują silne związki uczuciowe i materialne z Polską. Oficjalne statystki wskazują, że czasowa migracja przybiera formę długotrwałego pobytu. Dominujący po 2004 r. wzór czasowych migracji, przeważnie mężczyzn, uzupełniany jest przez długookresowe migracje rodzinne. W tym kontekście analiza materiałów zebranych w projekcie TRANSFAM wskazuje na podobieństwo ze wzorami obserwowanymi w Wielkiej Brytanii i Irlandii (Iglicka 2010; White 2009, 2011; Romejko 2015). Koncept płynnych migracji znajduje zastosowanie w analizie części migracji poakcesyjnych, ale tradycyjna perspektywa badawcza nie traci na swojej adekwatności.

\section{Bibliografia}

Alba R., Nee V. (1997), Rethinking Assimilation Theory for a New Era of Immigration, „International Migration Review", vol. 31(4), Special Issue: Immigrant Adaptation and Native-Born Responses in the Making of Americans, s. 826-874.

Baba M. L., Dahl-Jørgensen C. (2010), Work Migration from Poland to Norway: A New Institutional Approach, „iNtergraph: Journal of Dialogic Anthropology”, vol. 2 (2) (2010 Re-issue), http://intergraph-journal.net/enhanced/vol2issue2/2.html,

Bolt G., Ozuekren S., Phillips D. (2012), Introduction, w: Bolt G., Ozuekren A. S., Phillips D. (red.), Linking Integration and Residential Segregation, Abingdon: Routledge, s. 1-19.

Buhr F. (2014), Spatial Integration of Migrants: A Brief overview and Critique, IGOT/CEG-University of Lisbon INTEGRIM Online Papers, nr 1/2014, http://www.integrim.eu/ wp-content/uploads/2014/02/Buhr-Spatial-Integration-of-Migrants.pdf [data dostępu: 10.08.2015].

Buhr F. (2015), Becoming Local: Migrant Spatial Integration as a Skilled Practice, IGOT/CEG-University of Lisbon INTEGRIM Online Papers, nr 4/2015, http://www.integrim.eu/wp-content/uploads/2014/02/BUHR-Becoming-local-migrant-spatial-integration.pdf [data dostępu: 10.08.2015]. 
Burkiewicz Ł. (2015), Rozwój katolicyzmu w protestanckim kraju. Polacy w Norwegii, „Posłaniec”, nr 10/2015, http://www.opoka.org.pl/biblioteka/Z/ZP/poslaniec2015_10_norwegia. html [data dostępu:1.03.2017].

DaVanzo J. (1981), Repeat migration, information costs, and location specific capital, „Population and Environment", nr 4(1), s. 45-73.

Engbersen G., Snel E. (2013), Liquid migration. Dynamic and fluid patterns of post-accession migration flows, w: Glorius B., Grabowska-Lusinska I., Kuvik A (red.), Mobility in Transition Migration Patterns after EU Enlargement, Amsterdam: Amsterdam University Press, s. 21-41.

Engbersen G., Snel E., de Boom J. (2010), 'A van full of Poles': Liquid migration from Central and Eastern Europe, w: Black R., Engbersen G., Okólski M., Panțîru C. (red.), A Continent Moving West? EU Enlargement and Labour Migration from Central and Eastern Europe, Amsterdam: Amsterdam University Press, s. 115-141.

Faist S. (2000), The Volume and Dynamics of International Migration and Transnational Social Spaces, Oxford: Oxford University Press.

Friberg J. H. (2012), Culture at work: Polish migrants in the ethnic division of labour on Norwegian construction sites, „Ethnic and Racial Studies”, vol. 35(11), s. 1914-1933.

Friberg J. H., Tronstad R. K., Dølvik J. E. (2012), Central and Eastern European labour migration to Norway: trends, conditions and challenges, w: „Free Movement of Workers and Labour Market Adjustment: Recent Experiences from OECD Countries and the European Union", OECD Publishing, http://dx.doi.org/10.1787/9789264177185-en, [data dostępu: 7.09.2015] s. 147-172.

Glorius B., Grabowska-Lusinska I., Kuvik A. (2013), Concluding remarks, w: Glorius B.; Grabowska-Lusinska I., Kuvik A. (red.), Mobility in Transition Migration Patterns after EU Enlargement, Amsterdam: Amsterdam University Press, s. 309-325.

Gmaj K. (2016), Settling in Norway? The case of Polish migrants and their families, „Myśl Ekonomiczna i Polityczna", nr 2, http://www.lazarski.pl/pl/badania-i-rozwoj/oficyna-wydawnicza/Czasopisma-online/Mysl-Ekonomiczna-i-Polityczna/ [dostęp 1.09.2016], s. 163-191.

Huang L., Kochowicz M., Krzaklewska E., Pustulka P. (2015), TRANSFAM Web-survey on Polish families living in Polish-Norwegian transnationality. Documentation of design, variables and measures, http://www.transfam.socjologia.uj.edu.pl/documents/32445283/2f8f4dbc-e854-4c25-ba1f-a8262fb70f89 [data dostępu: 7.09.2015].

Huang L., Krzaklewska E., Pustulka P. (2016), Young Polish migrants in Norway: Education, work and settlement choice, „Tidsskrift For Ungdomsforskning”, vol. 16(1), https://journals.hioa.no/index.php/ungdomsforskning/article/view/1591 [data dostępu: 1.03.2017], s. 63-78.

Iglicka K. (2010), Powroty Polaków po 2004 roku. W pętli pułapki migracji, Warszawa: Scholar. Iglicka K., Gmaj K. (2015), Od integracji do partycypacji: wyzwania imigracji w Polsce i Europie, Warszawa: Scholar.

Iglicka K., Gmaj K., Wierzejski A. (2016), The Poles in Norway - we wanted workers but people arrived, „Myśl Ekonomiczna i Polityczna”, nr 1, http://www.lazarski.pl/pl/badania-i-rozwoj/oficyna-wydawnicza/Czasopisma-online/Mysl-Ekonomiczna-i-Polityczna/ [data dostępu: 1.09.2016], s. 116-138.

Iglicka K., Gmaj K., Wierzejski A. (2018), Contextualizing Polish Migration to Norway in the light of theory, statistical data and research findings, w: Slany K., Pustułka P., Guribye E., Ślusarczyk M. (red.), Transnational Polish Families in Norway. Social Capital, Integration, Institutions and Care, Warszawa: Peter Lang Edition, s. 43-70. 
Jałowiecki B., Szczepański M. (2006), Miasto i przestrzeń w perspektywie socjologicznej, Warszawa: Scholar.

Kaltenberg-Kwiatkowska E. (2007), Miasto rzeczywiste - miasto postrzegane. Pytania i uwagi socjologa, w: Madurowicz M. (red.), Percepcja współczesnej przestrzeni miejskiej, Warszawa: Wydawnictwo Uniwersytetu Warszawskiego.

King R., Thomson M., Fielding T., Warnes T. (2006), Time, Generations and Gender in Migration and Settlement, w: Penninx R., Berger M., Kraal K. (red.), The Dynamics of International Migration and Settlement in Europe. A State of the Art, Amsterdam: Amsterdam University Press, s. 233-269.

Kymlicka W. (2009), Współczesna filozofia polityczna, Warszawa: Fundacja Aletheia.

Levey G. B., Modood T. (2009), Secularism, Religion and Multicultural Citizenship, Cambridge: Cambridge University Press.

MacDonald J. S., MacDonald L. D. (1964), Chain Migration, Ethnic Neighborhood Formation, and Social Networks, „Milbank Memorial Fund Quarterly”, vol. 42(1), s. 82-97.

Modood T., Berthoud R., Lakey J., Nazroo J., Virdee S., Beishon S. (1997), Ethnic Minorities in Britain: Diversity and Disadvantage. The Fourth National Survey of Ethnic Minorities, London: Policy Studies Institute.

Napierała J., Trevena P. (2010), Patterns and determinants of sub-regional migration: A case study of Polish construction workers in Norway, w: Black R., Engbersen G., Okólski M., Panțîru C. (red.), A Continent Moving West? EU Enlargement and Labour Migration from Central and Eastern Europe, Amsterdam: Amsterdam University Press, s. 51-73.

Obwieszczenie Państwowej Komisji Wyborczej z dnia 27 października 2015 r. o wynikach wyborów do Sejmu Rzeczypospolitej Polskiej przeprowadzonych w dniu 25 października 2015 r. (Dz. U. z 2015 r., poz. 1731).

Philips A. (2009), Multiculturalism without Culture by Anne Phillips, Princeton: Princeton University Press.

Portes A., Guarnizo L. E., Landolt P. (red.), (1999), Transnational Communities. Special issue, „Ethnic and Racial Studies”, vol. 22(2).

Raciborski J. (2011), Obywatelstwo w perspektywie socjologicznej, Warszawa: Wydawnictwo Naukowe PWN.

Romejko A. (2015), Polacy w Wielkiej Brytanii. Interpretacja mimetyczna, Tuchów.

Statistics Norway (2017), Immigrants and Norwegian-born to immigrant parents, 1 January 2016, https://www.ssb.no/en/befolkning/statistikker/innvbef/aar/2016-03-03 [data dostępu: 1.03.2017] .

Thorud E., Stabbetorp L., Galloway T., Hårstad-Fonn K. (2014), International Migration 20132014 - IMO report for Norway, Oslo: Norwegian Ministry of Education and Research, Norwegian Ministry of Children, Equality and Social Inclusion, Norwegian Ministry of Justice and Public Security, Norwegian Ministry of Labour. https://www.regjeringen.no/contentassets/6857cc8822ee45208770edbd94fa5388/norway---imo-report-2013-2014-final.pdf [data dostępu: 27.11.2015].

Tuan Y. F. (1987), Przestrzeń i miejsce, Warszawa: Państwowy Instytut Wydawniczy.

Wallis A. (1990), Socjologia przestrzeni. Wybór prac, Warszawa: Niezależna Oficyna Wydawnicza.

White A. (2009), 'Family Migration from Small-Town Poland: a Livelihood Strategy Approach', w: Burrell K. (red.), Polish Migration to the UK, The 'New' European Union: After 2004, Farnham: Ashgate, s. 67-85.

White A. (2011), Polish Families and Migration since EU accession, Bristol: The Policy Press. 
Vertovec S. (2008), Migrant Transnationalism and Modes of Transformation, w: Portes A., De-

Wind J. (red.) Rethinking Migration. New Theoretical and Empirical Perspectives, New York Oxford: Berghahn Books, s. 149-180.

Vertovec S., Cohen R. (1999), Introduction, w: Vertovec S., Cohen R. (red.), Migration and Transnationalism, Aldershot: Edward Elgar, s. 13-28.

\section{Strony internetowe}

Kościół Rzymskokatolicki w Norwegii, https://www.katolsk.no [data dostępu: 1.03.2017]. Moja Norwegia, www.mojanorwegia.pl [data dostępu: 1.03.2017].

Statistics Norway, bazy danych, tabele, https://www.ssb.no [data dostępu: 1.03.2017].

UDI, Utlendingsdirektoratet, www.udi.no [data dostępu: 1.03.2017].

d-maps.com, http://www.d-maps.com/carte.php?num_car=24935\&lang=en [data dostępu: 1.03.2017]. 